\title{
O NORMIE PARAMETRYCZNEJ
}

\section{WSTĘP}

Niniejszy artykuł traktuje o normach parametrycznych jako specyficznych normach postępowania wyodrębnionych ze względu na przedmiot normowania. Parametr (gr. parametréo - odmierzam) - jest to „wielkość charakterystyczna dla danego materiału, procesu lub urządzenia; zmienna, która przyjmuje się za stałą w danym zagadnieniu, aby podkreślić jej odmienną rolę

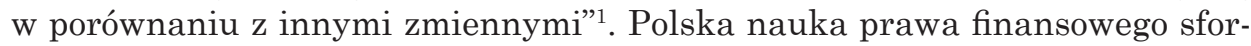
mułowała definicję normy parametrycznej - w 1977 r. Włodzimierz Nykiel zaproponował definicję w brzmieniu: „Norma parametryczna jest to taka norma prawna, której przedmiot współwyznaczają wielkości liczbowe (parametry)"2. Ujmował on zatem normę parametryczną jako normę prawna, a nadto proponował, aby przez owe wielkości liczbowe (parametry) rozumieć tylko te $\mathrm{z}$ nich, które będą określać dany układ lub wyznaczać jego stan. Za układ zaś będziemy uważać ów przedmiot normy prawnej, czyli regułę zachowania skierowana do jej adresata ${ }^{3}$.

Analiza dotychczasowego dorobku dotyczacego problematyki tzw. norm parametrycznych pozwala wskazać, że powstał on w czasach Polskiej Rzeczypospolitej Ludowej i bazuje na regulacjach prawnych ówcześnie obowiązują$\mathrm{cych}^{4}$. Dlatego też po ponad dwudziestu pięciu latach od transformacji ustrojowej wydaje się zasadna powtórna analiza normy parametrycznej, chociażby ze względu na zaistniałe zmiany legislacyjne - np. tzw. normy techniczne, które dotychczas były rozumiane jako klasyczne przykłady norm parametrycznych, utraciły status norm prawnych ${ }^{5}$. Dodatkowo wprowadzono do systemu praw-

\footnotetext{
${ }^{1}$ W. Doroszewski, Parametr, w: idem, Stownik Języka Polskiego, PWN, Warszawa 1960; internetowy Stownik języka polskiego PWN definiuje zaś słowo parametr jako: „zmienna, która przyjmuje się za stała $\mathrm{w}$ danym zagadnieniu, aby podkreślić jej odmienną rolę w porównaniu z innymi zmiennymi; wielkość charakterystyczna dla danego materiału, procesu lub urządzenia".

${ }^{2}$ W. Nykiel, Norma parametryczna, Acta Universitatis Lodzieniesis, Nauki Humanistyczno-Społeczne, Seria I, z. 19, 1977, s. 135-145.

${ }^{3}$ Ibidem, s. 140.

${ }^{4}$ Zob. W. Nykiel, op. cit., s. 135-145; L. Martan, Niektóre aspekty prawnej regulacji procesów mierzalnych, „Państwo i Prawo” 28, 1973, z. 8, s. 113-123; W. Lang, A. Malinowski, A. Mrózek, Prawometria $i$ jej zastosowanie w badaniu, tworzeniu $i$ stosowaniu prawa, „Państwo i Prawo” 27, 1972, z. 7, s. 17-30.

${ }^{5}$ Zob. art. 5 ust. 3 ustawy z 12 września 2002 r. - o normalizacji, Dz. U. 2002, Nr 196, poz. 1386 ze zm., który expressis verbis stanowi: „Stosowanie Polskich Norm jest dobrowolne”.
} 
nego takie normy prawa finansowego, które spełniają kryteria definicyjne normy parametrycznej6.

Przeobrażeniom uległ cały system prawa podatkowego w Polsce, który składa się z całego szeregu norm parametrycznych - chodzi tu o normy zawierajace w sobie stawki podatkowe. W poniższym artykule zostanie zanalizowana budowa normy parametrycznej na przykładzie norm prawa finansowego, prawa ochrony środowiska (tzw. norm emisyjnych), prawa budowlanego oraz tzw. norm technicznych ${ }^{7}$.

Jednakże, aby móc zaproponować chociażby korektę owej definicji, należy ustalić na wstępie zakres normowania normy parametrycznej oraz stosunek zbioru norm parametrycznych do zbioru norm prawnych. Przyjmijmy jednak na razie jako hipotezę roboczą pewną modyfikację definicji zaproponowanej przez W. Nykiela o następującym brzmieniu: za normę parametryczną będziemy uważać taką normę postępowania, której przedmiot jest współwyznaczany przez wielkość liczbową (parametr).

\section{POZAPRAWNE NORMY PARAMETRYCZNE}

W życiu codziennym napotkać możemy wiele norm parametrycznych. Najlepszym ich przykładem są tzw. normy techniczne, które traktują o wymaganiach technicznych, jakie winny spełniać towary i usługi, aby mogły zostać dopuszczone do obrotu. Dla przykładu zanalizujmy rozporządzenie Ministra Infrastruktury z 12 kwietnia 2002 r. - w sprawie warunków technicznych, jakim powinny odpowiadać budynki i ich usytuowanie. W rozdziale $8 \S 97$ pkt 8 możemy przeczytać, iż: „Pomieszczenia techniczne przeznaczone do układania kabli w budynku (tunele i pomieszczenia kablowe) powinny spełniać wymagania wynikające z normy Stowarzyszenia Elektryków Polskich nr N SEP-E-004:2003 Elektroenergetyczne i sygnalizacyjne linie kablowe. Projektowanie i budowa" - jest to klasyczny zabieg odesłania przez ustawodawcę do innego systemu norm, a mianowicie do zbioru norm technicznych, ustanowionych przez organizację zajmującą się w sposób fachowy opracowywaniem zagadnień technicznych odnośnie do specyfikacji, w tym przypadku pomieszczeń technicznych do układania kabli w budynkach ${ }^{8}$.

${ }^{6}$ Zob.: ustawa z 26 listopada 1998 r. o finansach publicznych, Dz. U. 1998, Nr 155, poz. 1014 ze zm. - Nauka prawa finansowego określa je niekiedy jako „,reguły fiskalne”, co jest moim zdaniem - błędne, gdyż są to obowiązujące normy prawne wyrażone expressis verbis w ustawie; zob. np.: D. Mączyński, Procedury ostrożnościowe $i$ sanacyjne - instrument ochrony przed nadmiernym zadtużeniem?, w: A. Pomorska, J. Szołno-Koguc (red.), Ekonomiczne i prawne uwarunkowania i bariery redukcji deficytu i długu publicznego, 2011, Lex/el. 144450.

${ }^{7}$ Chodzi tutaj o zbiór norm technicznych zatwierdzanych przez Polski Komitet Normalizacyjny, które to dotyczą wartości wielkości liczbowych charakterystycznych dla danych towarów i usług - nosi nazwę Polskie Normy.

${ }^{8}$ Odnośnie do tego, czym jest odesłanie w tekście prawnym, zob. np: M. Zieliński, Wykładnia prawa. Zasady, reguły, wskazówki, Warszawa 2017; L. Leszczyński, Stosowanie generalnych klauzul odsytajacych, Kraków 2001. 
Sytuacja ta jest pozornie prosta: ustawodawca zastosował klasyczny zabieg legislacyjny odesłanie i odesłał nas do innego zbioru norm. Przyjrzyjmy się jednak podmiotowi, który ów zbiór stanowi. Jest to Stowarzyszenie Elektryków Polskich, które jest osobą prawną i działa na podstawie ustawy - Prawo o stowarzyszeniach. Normy techniczne stanowione przez owe stowarzyszenie nie są normami prawnymi (ich skuteczność jest ograniczona do członków stowarzyszenia) ${ }^{9}$. Przy czym należy zauważyć, że posługiwanie się przez ustawodawcę odesłaniami do systemu norm stanowionych przez to stowarzyszenie jest aktem aprobaty dla norm przez ową organizacje stanowionych.

Za ratio legis stanowienia owych odesłań można przyjać, iż posiadając pewien wzorzec ustanowiony przez organizację fachową zajmujaccą się pewną dziedzina wiedzy, ustawodawca ułatwia zadanie podmiotom stosujacym prawo. W przypadku niezastosowania się do danej normy przez adresata (np. osobę wykonujaccą instalację elektryczna) sąd, dokonując aktu stosowania prawa, ma możliwość porównania stanu zastanego (zazwyczaj za pomoca opinii biegłego) ze wzorcem opracowanym przez stowarzyszenie fachowe, do którego odsyła rozporządzenie.

W przypadku braku takiego wzorca (a odwołaniem się do zwrotu niedookreślonego, np. zgodnie ze sztuką bądź zgodnie z aktualną wiedza) sytuacja podmiotu stosującego prawo jest trudniejsza. Winien on wpierw zebrać opinie biegłych z zakresu danej dziedziny wiedzy (aby w danym przypadku móc dookreślić to wyrażenie) i przekonać sąd do tego, że podmiot winien się zastosować do takich, a nie innych zaleceń (przy czym sąd zmuszony by był dopuścić przeciwdowód z opinii innych biegłych, którzy mogliby zakwalifikować dany przypadek zupełnie odmiennie, co dodatkowo komplikowałoby sprawę). Ustanowienie odesłania do norm fachowych stanowionych przez organizację fachowa, bez watpienia zatem ułatwia stosowanie tzw. norm technicznych. (Co dezawuuje możliwości powołania przeciwdowodu z opinii biegłego).

Ustawodawca ma jednak możliwość odesłać nas do systemu norm technicznych innych niż stanowione przez organizacje fachowe w danej dziedzinie wiedzy - mianowicie do norm technicznych stanowionych przez Polski Komitet Normalizacyjny ${ }^{10}$. Takim przykładem jest rozporządzenie Ministra Pracy i Polityki Socjalnej z 26 września 1997 r. w sprawie ogólnych przepisów bezpieczeństwa i higieny pracy. Paragraf 4 pkt 2 owego rozporządzenia stanowi: „Drogi i przejścia powinny posiadać wymiary odpowiednie do liczby potencjalnych użytkowników oraz rodzajów i wielkości stosowanych urządzeń transportowych i przemieszczanych ładunków. Minimalne wymiary dróg i przejść

9 Za normę prawną przyjmujemy normę postępowania ustanowioną bądź usankcjonowaną przez kompetentny organ państwa.

${ }^{10}$ W kontekście poprzedniego przykładu należy tutaj wspomnieć, że praktykowane jest przez autorów norm technicznych stanowionych przez organizacje fachowe stosowanie odesłań do norm stanowionych przez komitety techniczne PKN - przykładem jest tutaj wspomniana norma Stowarzyszenia Elektryków Polskich nr N SEP-E-004:2003 Elektroenergetyczne $i$ sygnalizacyjne linie kablowe. Projektowanie $i$ budowa - która już w swojej przedmowie zawiera listę norm powołanych, wśród których znajdują się tylko Polskie Normy stanowione przez komitety PKN. Szerzej zob.: Norma SEP N SEP - E - 004 Elektroenergetyczne i sygnalizacyjne linie kablowe. Projektowanie i budowa, COSiW SEP, Warszawa 2008, s. 1. 
określają Polskie Normy"11. Normy techniczne stanowione przez poszczególne komitety techniczne PKN nie sa jednak normami prawnymi ${ }^{12}$. Świadczy o tym art. 5 ust. 3 ustawy z 12 września 2002 r. o normalizacji ${ }^{13}$. Dopuszczone jest jednak powoływanie się na nie w przepisach prawnych po ich opublikowaniu w języku polskim - zgodnie z art. 5 ust. 4 tej ustawy ${ }^{14}$.

Pełna analiza pozaprawnej normy parametrycznej - jaka stanowi norma SEP N SEP - E - 004 Elektroenergetyczne i sygnalizacyjne linie kablowe. Projektowanie i budowa - jest jednak utrudnione ze względu na objętość owej normy (jej pełna dokumentacja obejmuje 10 stron maszynopisu). Dlatego też dokonamy analizy jedynie wybranego fragmentu owej normy, aby unaocznić podobieństwa i różnice w budowie względem normy prawnej. Redakcyjnie norma ta jest rozbita na szereg punktów i podpunktów. Przyjrzyjmy się jej punktowi 3.2.2, który stanowi: „Głębokość umieszczenia osłon otaczających w ziemi, mierzona od powierzchni terenu do górnej powierzchni osłony linii kablowej o napięciu znamionowym nie wyższym niż $30 \mathrm{kV}$, powinna wynosić co najmniej: $40 \mathrm{~cm}$ - przy układaniu kabli pod chodnikami, $80 \mathrm{~cm}$ - przy układaniu kabli w częściach dróg i ulic przeznaczonych do ruchu kołowego. [...] Głębokość umieszczenia osłon otaczających w ziemi, mierzona od powierzchni terenu do górnej powierzchni osłony linii kablowej o napięciu znamionowym wyższym niż $30 \mathrm{kV}$, powinna wynosić co najmniej $100 \mathrm{~cm}$ ”.

Jak można zauważyć, cytowany fragment wskazuje na interesujace nas wartości liczbowe (parametry) w postaci odległości liczonych w centymetrach oraz wielkości napięcia liczonego w kilowoltach. Analiza budowy tej normy wymaga jednak przyjęcia pewnych założeń. Po pierwsze, w przypadku przyjęcia, że do zrekonstruowania takowej normy wystarczy tylko akt prawny organizacji fachowej, będzie nas prowadziło do wniosku, iż jest to norma składająca się w myśl trójczłonowej koncepcji budowy normy prawnej, tylko z hipotezy i dyspozycji - a zatem będzie to norma niedoskonała (lex imperfecta). Brak bowiem w akcie prawa wewnętrznego sankcji za przekroczenie owej normy - a w przypadku gdyby takową sankcję ów akt prawa wewnętrz-

11 To, czym są Polskie Normy, definiuje art. 5 ust. 1 ustawy z 12 września 2002 r. o normalizacji, Dz. U. 2015, poz. 1483.

12 Polski Komitet Normalizacyjny jest bowiem państwową osobą prawna, nie ma jednak kompetencji do stanowienia norm prawnych.

${ }^{13}$ Dz. U. 2015, poz. 1483. Przy czym należy zauważyć, że Polski Komitet Normalizacyjny do 1994 r. był organem stanowiącym powszechnie obowiązujące Polskie Normy mające status norm prawnych. W związku z transformacją ustrojową i odejściem od gospodarki nakazowo-rozdzielczej ustawodawca zdecydował się na pozbawienie Polskich Norm statusu norm prawnych - ich stosowanie jest dobrowolne.

${ }_{14}$ Jednakże jest tam ujęta tylko możliwość powoływania w przepisach prawnych Polskich Norm - co nie przesądza o bezwzględności ich stosowania - racjonalny ustawodawca, mając do dyspozycji zbiór Polskich Norm jako norm fachowych, po prostu odsyła nas do niego. Można wyobrazić sobie sytuację, że podmiot, którego obowiązek jest kształtowany przez taką normę, występuje na drogę sądowoadministracyjną i na mocy art. 5 ust. 3 owej ustawy doprowadza do odstapienia od stosowania danej normy technicznej w określonym przypadku. Odesłania, o których tu mowa, funkcjonują bowiem w akcie wykonawczym, jakim jest rzeczone rozporządzenie, który to hierarchicznie jest niżej niż ustawa, przez co w przypadku niezgodności norm z aktu wykonawczego z normami ustawowymi sąd może odmówić stosowania tych pierwszych. 
nego zawierał, to jej skuteczność ograniczona by była tylko do członków stowarzyszenia ${ }^{15}$.

Po drugie, w przypadku przyjęcia, że aby zrekonstruować daną normę, należy sięgnąc także do innych aktów prawnych (w tym do aktów prawa powszechnie obowiązującego, jakim jest zarówno wspomniane wyżej rozporządzenie, które odsyła nas do owej normy organizacji fachowej, oraz ustawa z 7 lipca 1994 r. - Prawo budowlane, na podstawie której wydano to rozporządzenie, to otrzymamy normę doskonałą pod względem budowy (lex perfecta), składajaca się z hipotezy, dyspozycji i sankcji ${ }^{16}$. Przy czym w tym momencie należy zwrócić uwagę, że norma zrekonstruowana chociażby w części z przepisów powszechnie obowiązujących oraz zwierająca w sobie sankcję karną za jej przekroczenie jest już traktowana jako obowiąujacca norma prawna.

Można też zanalizować jej budowę z punktu widzenia koncepcji dwóch norm funkcjonalnie sprzężonych. W tym przypadku należałoby przyjać, że norma parametryczna, o której mowa, jest to norma sankcjonowana ze względu na jakąśs inną normę, która aktualizuje się dopiero w momencie naruszenia owej normy sankcjonowanej ${ }^{17}$. Ten przypadek jest jednak o tyle ciekawszy, że mamy dwie normy funkcjonalnie sprzężone - normę parametryczną będąca normą sankcjonowaną (która jest zrekonstruowana z przepisów aktów prawa wewnętrznego) oraz normę sankcjonującą ową normę sankcjonowaną wynikająca z aktów prawa powszechnie obowiązującego (przepisów ustawy). Wtedy też należałoby przyjacc, że ustawodawca sankcjonowałby normę wynikająca z aktów wewnętrznych organizacji fachowej - koncepcja dwóch norm funkcjonalnie sprzężonych pozwoli nam rozbić normę parametryczną na zespół dwóch norm i łatwiej ukazać ich budowę ${ }^{18}$.

Dlatego też w tym miejscu przyjmiemy, że normy parametryczne będa analizowane tylko w myśl koncepcji dwóch norm funkcjonalnie sprzężonych. Pierwsza z owych norm - norma sankcjonowana zawierajaca w sobie parametr będzie mieć postać: „Nakazuje się, aby głębokość umieszczenia osłon kablowych otaczajacych w ziemi, mierzona od powierzchni terenu do górnej powierzchni osłony linii kablowej o napięciu znamionowym nie wyższym niż $30 \mathrm{kV}$, winna wynosić co najmniej $40 \mathrm{~cm}$ - przy układaniu pod chodnikami, o najmniej $80 \mathrm{~cm}$ - przy układaniu kabli w częściach dróg i ulic przeznaczonych do ruchu kołowego, a w przypadku napięcia powyżej $30 \mathrm{kV}$ - co najmniej $100 \mathrm{~cm}$ ".

Z kolei druga z zespołu dwóch norm funkcjonalnie sprzężonych - norma sankcjonująca będzie mieć postać: „Nakazuje się sądowi każdemu, kto nie spełni wymagań dotyczących głębokości umieszczenia osłon kablowych w zie-

15 Jest to sprzeczne z konstytucyjną zasadą nulla poena sine lege, wynikającą z art. 42 Konstytucji Rzeczypospolitej Polskiej.

${ }_{16}$ Sankcja zaś jest ustanowiona w przepisach karnych ustawy z 7 lipca 1994 r. - Prawo budowlane, Dz. U. 2016, poz. 1250.

17 Jako podmiot, którego obowiązek zaktualizowałby się w przypadku naruszenia owej normy sankcjonowanej, należałoby tutaj wskazać Państwową Inspekcję Budowlaną.

${ }^{18}$ Co do takiej możliwości zob. np: W. Lang, System prawa i porzadek prawny, w: O. Bogucki, S. Czepita (red.), System prawa a porzqdek prawny, Rozprawy i Studia Uniwersytetu Szczecińskiego, t. 756, Szczecin 2008, s. 22. 
mi, wymierzyć karę grzywny"19. Bez wątpienia norma sankcjonująca będzie w tym przypadku norma prawna, jednakże co do statusu normy sankcjonowanej można mieć wątpliwości.

\section{PRAWNE NORMY PARAMETRYCZNE}

W zbiorze norm prawnych obowiąują także expressis verbis normy, które są normami parametrycznymi. Przykładem niech będzie rozporządzenie Ministra Infrastruktury z 12 kwietnia 2002 r. w sprawie warunków technicznych, jakim powinny odpowiadać budynki i ich usytuowanie, gdzie w rozdziale 9 $\S 43$ możemy przeczytać, iż: „Szerokość bramy powinna wynosić w świetle co najmniej 2,4 m, a przypadku zastosowania furtki jej szerokość powinna być nie mniejsza niż $0,9 \mathrm{~m}$, przy czym na drodze pożarowej szerokości te regulują przepisy odrębne dotyczace ochrony przeciwpożarowej”. Jest to najprostszy przykład normy parametrycznej, której przedmiot jest współwyznaczany przez wielkość liczbową (parametr), wyrażoną w jednostce długości - metrach. W tym przypadku kompetentny organ państwa ustanowił normę prawną wedle koncepcji obowiązywania normy prawnej ${ }^{20}$. Jest też to norma techniczna, która została w sposób bezpośredni wysłowiona w przepisach prawnych, bez uciekania się przez ustawodawcę do zabiegów legislacyjnych w postaci odesłań do zbiorów norm pozasystemowych. W świetle koncepcji trójczłonowej budowy normy prawnej norma ta będzie miała postać: „Każdy, kto wznosi budynek mieszkalny wyposażony w bramę, obowiązany jest do zapewnienia jej szerokości w świetle co najmniej $2,4 \mathrm{~m}$, a w przypadku zastosowania furtki do zapewnienia jej szerokości co najmniej 0,9 m [...], w przeciwnym razie podlega karze grzywny".

W przypadku zaś zastosowania koncepcji dwóch norm funkcjonalnie sprzężonych norma sankcjonowana będzie mieć postać: „Nakazuje się, aby bramy budynków mieszkalnych miały w świetle co najmniej $2,4 \mathrm{~m}$, a w przypadku zastosowania furtki jej szerokość była nie mniejsza niż 0,9 m [...]”. Norma sankcjonujacca przyjmie w tym przypadku postać: „Nakazuje się Państwowej Inspekcji Budowlanej każdemu, kto wzniesie budynek mieszkalny wyposażony w bramę, której szerokość jest mniejsza niż dopuszczalna (także w przypadku furtki), wymierzenie kary grzywny".

Drugim przypadkiem, który warto rozpatrzyć, jest tzw. norma emisyjna, będąca $\mathrm{w}$ istocie standardem emisyjnym ${ }^{21}$ zawartym $\mathrm{w}$ rozporządzeniu Ministra Środowiska w sprawie standardów emisyjnych dla niektórych rodzajów instalacji, źródeł spalania paliw oraz urządzeń spalania lub współspalania odpadów,

${ }^{19}$ Druga z owych norm została wyinterpretowana z przepisów karnych ustawy z 7 lipca 1994 r. - Prawo budowalne, Dz. U. 2016, poz. 1250.

20 O koncepcjach obowiązywania normy prawnej zob. np: Z. Ziembiński, Problemy podstawowe prawoznawstwa, Warszawa 1980; także L. Nowak, Cztery koncepcje obowiazywania prawa, „Ruch Prawniczy, Ekonomiczny i Socjologiczny” 30, 1968, z. 2.

21 Szerzej, czym są standardy emisyjne, zob. np: K. Gruszecki, Prawo ochrony środowiska. Komentarz, Warszawa 2016, s. 401 i n. 
wydawanym na podstawie art. 146 ust. 3 ustawy z 27 kwietnia 2001 r. - Prawo ochrony środowiska. W tym przypadku jednak w rozporządzeniu zawarty jest cały szereg wielkości liczbowych (parametrów), które współkształtują nam przedmiot normy prawnej. Na przykład: $§ 19$ pkt 5 stanowi: „Podawanie odpadów do instalacji albo urządzeń spalania lub współspalania odpadów wstrzymuje się natychmiast także w przypadku spadku temperatury w komorze spalania poniżej $850^{\circ} \mathrm{C}$, a przy spalaniu odpadów niebezpiecznych zawierających ponad $1 \%$ związków chlorowcoorganicznych w przeliczeniu na chlor - poniżej $1100^{\circ} \mathrm{C}$ ". Norma sankcjonowana przyjmie zatem postać: „Nakazuje się wstrzymanie procesu podawania odpadów do procesu współspalania w przypadku spadku temperatury w komorze spalania poniżej $850^{\circ} \mathrm{C}$, a przy spalaniu odpadów niebezpiecznych zawierajacych ponad $1 \%$ związków chlorowcoorganicznych w przeliczeniu na chlor - poniżej $1100^{\circ} \mathrm{C}$ ". Norma sankcjonująca przyjmie zaś postać: „Nakazuje się sądowi w przypadku przekroczenia standardów emisyjnych wymierzyć karę grzywny" "22.

\section{STOSUNEK ZBIORU POZAPRAWNYCH NORM PARAMETRYCZNYCH DO ZBIORU PRAWNYCH NORM PARAMETRYCZNYCH}

Przytoczone powyżej przykłady norm parametrycznych, zarówno tych pozaprawnych, jak i prawnych, ilustruja, że zbiór norm parametrycznych nie jest zbiorem tożsamym ze zbiorem norm prawnych. Z jednej strony obowiązuja bowiem normy parametryczne niebędące normami prawnymi (gdyż są stanowione przez organizacje branżowe), z drugiej zaś - obowiązują normy prawne niebędace normami parametrycznymi. Obowiązują wreszcie takowe normy parametryczne, które są też normami prawnymi. Nadto należy dodać, że zgodnie z zaproponowaną hipotetyczną definicją normy parametrycznej zbiór norm parametrycznych należy uznać za podzbiór norm postępowania i ponadto że zbiór norm prawnych także jest podzbiorem norm postępowania (jeżeli przyjąć, że norma prawna to norma postępowania ustanowiona bądź usankcjonowana przez kompetentny organ państwa). Dlatego też zbiory: norm parametrycznych i norm prawnych mają swoją część wspólną (iloczyn), zawieraja się zaś w zbiorze norm postępowania.

Zatem można zapisać stosunek zbioru norm parametrycznych do zbioru norm prawnych w następujący sposób:

Niech $A$ będzie zbiorem pozaprawnych norm parametrycznych, zaś $B$ będzie zbiorem norm prawnych. Jeżeli zbiór pozaprawnych norm parametrycznych ma część wspólną ze zbiorem norm prawnych, to:

$$
X \in(A \cap B) \Leftrightarrow(X \in A) \wedge(X \in B),
$$

\footnotetext{
22 Art. 339 ustawy z 27 kwietnia 2001 r. - Prawo ochrony środowiska, Dz. U. 2016, poz. 672.
} 
zbiór norm prawnych parametrycznych można zaś zapisać jako:

$$
X \in C \Leftrightarrow X \in(A \cap B) .
$$

Dla lepszego unaocznienia owego zagadnienia posłużymy się schematem.

Schemat 1

Stosunek zbioru norm parametrycznych do zbioru norm prawnych

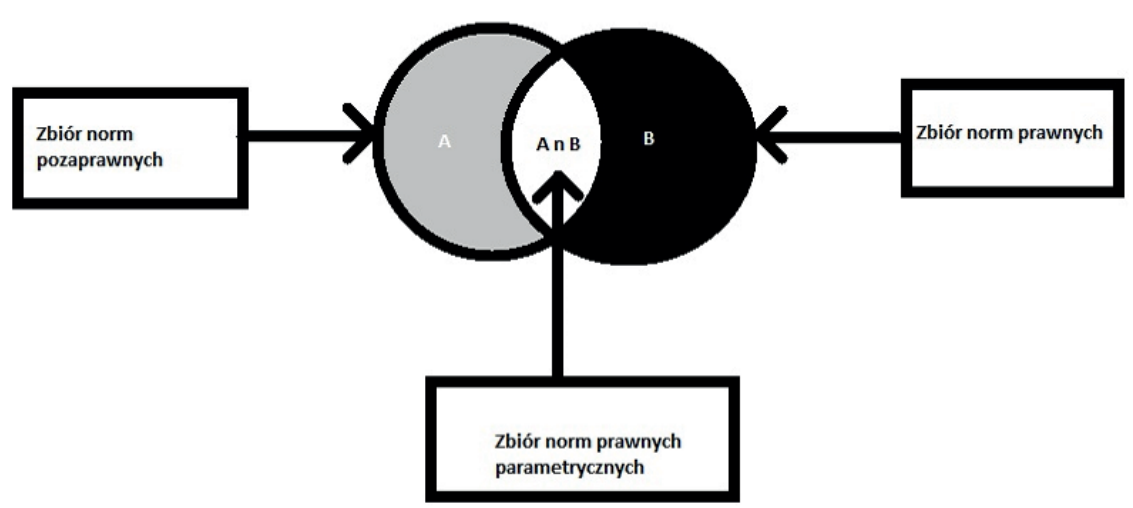

Źródło: opracowanie własne.

Alternatywne ujęcie stosunku zbioru norm parametrycznych do zbioru norm prawnych, związane z definicją zaproponowana przez W. Nykiela, wynikało $\mathrm{z}$ faktu, że w momencie definiowania normy parametrycznej panowały odmienne realia życia polityczno-społecznego. Po pierwsze, należy przypomnieć, że w okresie PRL wszelkie normy techniczne miały status norm prawnych, co wynikało z ustawy o normalizacji. Nadto inne normy parametryczne (takie jak normy prawa budowlanego, podatkowego, finansowego czy ochrony środowiska) stanowione były przez właściwe organy państwa. Oczywiście obowiązywały w systemie także inne, specyficzne normy, dotyczace np.: zasad bezpieczeństwa na morzu (na podstawie których orzekały Izby Morskie), jednakże były to przypadki regulowane za pomocą umów międzynarodowych ${ }^{23}$. Dlatego też W. Nykiel uznał, że zbiór norm parametrycznych zawiera się w zbiorze norm prawnych. Można to zapisać w następujący sposób:

$$
(A \subset B) \Leftrightarrow(X \in A) \Rightarrow(X \in B) .
$$

${ }^{23}$ Zob. np: Konwencja SOLAS z 1 listopada 1974 r., ratyfikowana przez PRL 16 lutego 1984 r., Dz. U. Nr 61, poz. 318. 
Dla lepszego przedstawienia posłużymy się schematem.

Schemat 2

Stosunek zbioru norm parametrycznych do zbioru norm prawnych według W. Nykiela

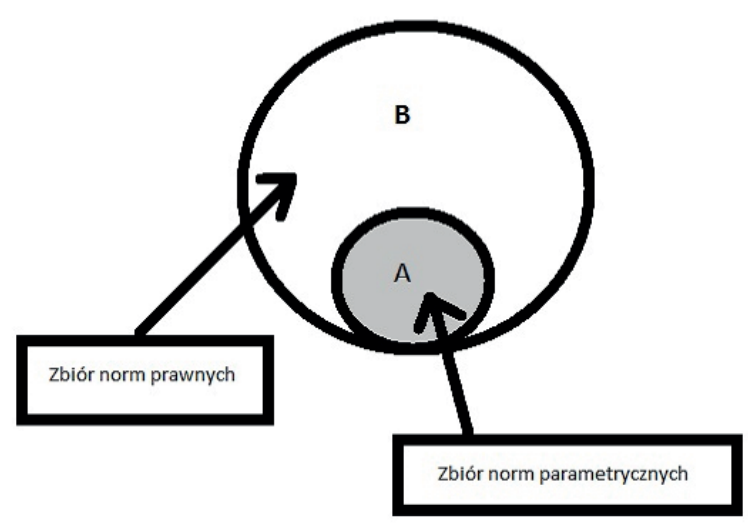

Źródło: opracowanie własne.

Takie rozumienie jest jednak obecnie nieadekwatne ze względu na fakt istnienia takich norm parametrycznych, które nie są normami prawnymi.

\section{POSTAĆ REDAKCYJNA NORMY PARAMETRYCZNEJ}

W tym miejscu zajmiemy się analizą normy prawnej parametrycznej. Analizować jej budowę można w ramach klasycznej, trójczłonowej koncepcji budowy normy prawnej albo uznać, że norma parametryczna jest zespołem dwóch norm funkcjonalnie sprzężonych. Jak już wyżej wspomniano, przedmiot owej normy jest współwyznaczany przez wielkości liczbowe (parametry). Według koncepcji trójczłonowej swoje miejsce znajdzie wielkość liczbowa (parametr) w pierwszym członie, to jest hipotezie. Na przykład: ,,Jeśli relacja jednej wielkości do drugiej wyniesie $X$ ” albo ,,Jeśli przedmiot posiada cechę $Y$ ” albo ,,Ilekroć zaistnieje taki stan rzeczy, że dana wielkość liczbowa wyniesie $Z$ '. Takie umiejscowienie wynika $\mathrm{z}$ tego, że tylko w tym miejscu jest on w stanie współkształtować to, o czym dana norma traktuje. Obowiązek adresata (określone zachowanie się) zaktualizuje się bowiem w momencie, gdy dana wielkość liczbowa (parametr) osiagnie określoną wartość.

W odniesieniu do koncepcji dwóch norm funkcjonalnie sprzężonych ${ }^{24}$ sytuacja jest znacznie bardziej skomplikowana. Z jednej bowiem strony można

${ }^{24}$ Zob. J. Lande, Nauka o normie prawnej, „Annales UMCS” 3, 1956; Z. Ziembiński, op. cit., s. $154-157$. 
by przyjąć, że należałoby umiejscowić wielkość liczbowa (parametr) w normie sankcjonowanej. Można ją spróbować ująć następująco: „Jeśli zajdą okoliczności takie, że $O$, parametr $P$, osiagnie wielkość $W$ ". Druga z nich, czyli norma sankcjonująca, będzie mieć postać: „Jeśli osiagnięto wielkość $W$, to adresat $A$, powinien czynić $Z$ ”. Pomiędzy tymi normami istnieje sprzężenie funkcjonalne, polegające na aktualizowaniu się obowiązku adresata $A$ i czynieniu $Z$ w momencie osiagnięcia wartości $W$ przez parametr $P$ ze względu na zajście okoliczności $O$.

W tym miejscu należy poczynić kilka uwag. Po pierwsze, koncepcja dwóch norm funkcjonalnie sprzężonych znalazła szczególne zastosowanie na gruncie dogmatyki prawa karnego materialnego i tam dominuje $\mathrm{w}$ opisie normy prawnokarnej ${ }^{25}$. Po drugie, normy zawierające w swoim przedmiocie wartość liczbowa (parametr) są o tyle specyficzne, że zachowanie adresata normy jest uzależnione od wartości, jaka przyjmuje w danym czasie dana wielkość liczbowa (parametr) - a zatem w powyższym przypadku do aktualizacji obowiązu adresata normy sankcjonujacej dochodzi w momencie osiagnięcia danej wartości przez wspomnianą wielkość liczbową (parametr) z normy sankcjonowanej.

Przyjrzyjmy się dla przykładu fragmentowi normy z art. 86 ustawy o finansach publicznych (u.f.p.). Norma ta (która jest normą sankcjonowana) zawiera zatem odniesienie do bytu abstrakcyjnego, jakim jest np. relacja państwowego długu publicznego do produktu krajowego brutto (w rozumieniu art. 86 u.f.p.). Wartość owej relacji w ujęciu procentowym jest interesująca nas wielkością liczbową (parametrem). Z kolei norma sankcjonująca, która jest funkcjonalnie sprzężona $\mathrm{z}$ normą sankcjonowaną $\mathrm{z}$ art. 86 u.f.p., zawiera w sobie określenie adresata, którym jest Rada Ministrów. Nakazuje się jej, aby w przypadku osiagnięcia przez wspomnianą wielkość liczbowa (parametr) określonej wielkości, podjęli szereg działań ukierunkowanych na zmniejszenie owej wartośsi ${ }^{26}$. Dlatego też, aby dowiedzieć się, czy dojdzie do aktualizacji obowiązku adresata, należy w pierwszej kolejności znać wartość wielkości liczbowej (parametru). Ustalenie jednak wartości interesujących nas wielkości (parametru), czyli owej relacji państwowego długu publicznego do produktu krajowego brutto, wymaga jednak ustalenia, czym w istocie jest państwowy dług publiczny oraz produkt krajowy brutto. W sukurs przychodzi nam ustawodawca, który oba te terminy definiuje w stosownych ustawach ${ }^{27}$. Jednakże oba wspomniane terminy okazują się

${ }^{25}$ Zob. np: Ł. Pohl, Struktura normy sankcjonowanej w prawie karnym. Zagadnienia ogólne, Poznań 2007, s. 282.

${ }^{26}$ Ustawodawca nakłada na Radę Ministrów szereg obowiązków, odnośnie do treści przyszłorocznego budżetu m.in. nakazuje się uchwalenie ustawy budżetowej bez planowanego deficytu bądź relacja wielkości liczbowej (parametru) będzie na koniec roku budżetowego niższa niż bieżąca.

${ }^{27}$ Państwowy dług publiczny zdefiniowano w art. 72 ustawy o finansach publicznych, Dz. U. 2016, poz. 1454 ze zm. obliczanie zaś produktu krajowego brutto jest zdefiniowane odrębnie w ustawie z 26 października 2000 r. o obliczaniu produktu krajowego brutto, Dz. U. 2000, Nr 98, poz. 817 ze zm. - z której to można wyprowadzić definicję produktu krajowego brutto. 
wielkościami liczbowymi (parametrami). A zatem wartość jednych wielkości liczbowych (parametrów) - tutaj interesującej nas relacji państwowego długu publicznego do produktu krajowego brutto - jest zależna od wartości innych wielkości liczbowych (parametrów) - można zatem zauważyć, że zachodzi między nimi relacja zależności będąca konsekwencją zabiegu legislacyjnego zastosowanego przez ustawodawcę, polegającego na odesłaniu (wewnętrznym bądź zewnętrznym) w celu ustalenia znaczenia danego terminu.

W przypadku klasycznych norm podatkowych, zawierajacych stawki podatku, norma parametryczna jest zazwyczaj kumulacją pewnych wielkości liczbowych (parametrów) i może przybrać jeszcze inną postać, a mianowicie: „Jeśli przedmiot $P$, posiada cechy $C, D, E$, to podatnik winien zastosować stawkę $S$ ”. Na przykład: jeżeli grunt jest własnością osoby fizycznej nieprowadzącej działalności gospodarczej na tym gruncie i nie podlega ustawowym wyłączeniom od opodatkowania, to należy zastosować przy obliczaniu podatku stawkę $S$ - to jest pomnożyć powierzchnię wyrażoną w metrach kwadratowych razy stawkę $^{28}$. Dany przedmiot (w naszym przypadku grunt) posiada tutaj szereg cech. Wartość parametru, czyli interesującej nas wielkości liczbowej (w tym przypadku stawki), jest uzależniona od tego, czy dany przedmiot posiada dane cechy czy też nie. W zależności od tego, czy warunek posiadania danych cech jest spełniony, wolno zastosować podatnikowi daną stawkę do opodatkowania danego gruntu. Można by zatem rzec, że de facto mamy tu do czynienia z dwoma parametrami - po pierwsze powierzchnia gruntu jako wielkość liczbowa (parametr) wyznacza nam podstawę opodatkowania. Im bowiem grunt większy, tym wysokość kwoty podatku rośnie. Następnie, kiedy ustalimy także szereg innych cech, możemy dokonać przyporządkowania odpowiedniej stawki do danego rodzaju gruntu i związanej z nim powierzchni wyrażonej w metrach kwadratowych. Zatem stawka także będzie parametrem, który to będzie odpowiadał za wysokość kwoty podatku. Jednakże dopiero oba te parametry pomnożone przez siebie (ich iloczyn) dadzą nam ostateczną odpowiedź, jaka jest kwota podatku do zapłacenia.

Zmodyfikujmy powyższy przykład. Załóżmy, że ustawodawca wprowadza rozróżnienie względem powierzchni gruntu. Jeżeli zatem grunt ma powierzchnię nieprzekraczająca $100 \mathrm{~m}^{2}$ (przy zachowaniu cech wyżej wymienionych), to należy odwołać się do formuły obliczenia wartości kwoty podatku jak powyżej (czyli iloczyn powierzchni i stawki daje nam kwotę). W przypadku gdy powierzchnia gruntu przekroczy rzeczone $100 \mathrm{~m}^{2}$, ustawodawca przyjmuje inny sposób obliczania kwoty, a mianowicie do iloczynu powierzchni i stawki nakazuje dodać do wartości kwoty podatku dla każdego metra powierzchni przekraczającego rzeczone $100 \mathrm{~m}^{2}$ kwotę 20 zł. A zatem

\footnotetext{
28 Jest to oczywiście tylko wielce uproszczone i przykładowe zrekonstruowanie normy dotyczącej opodatkowania gruntów podatkiem od nieruchomości przez osoby fizyczne nieprowadzące na nich działalności gospodarczej. Nie uwzględniono tutaj np. tego, kto ustala stawkę podatku czy też kiedy powstaje obowiązek podatkowy. Pełne odtworzenie danej normy wymagałoby analizy szeregu przepisów ustawy z 12 stycznia 1991 r. o podatkach i opłatach lokalnych, co jest przedmiotem analizy dogmatyki podatkowej.
} 
aby obliczyć kwotę podatku, należy wpierw ustalić, jaką powierzchnię ma grunt, następnie ustalić stawkę dla każdego metra kwadratowego powierzchni, po czym ustalić, o ile rzeczona powierzchnia przekracza owe $100 \mathrm{~m}^{2}$ (dla przykładu załóżmy, że nasz grunt ma $110 \mathrm{~m}^{2}$, a stawka za metr kwadratowy wynosi $5 \mathrm{zl}$ ) - a zatem od $110 \mathrm{~m}^{2}$ odejmujemy $100 \mathrm{~m}^{2}$ i daje nam to $10 \mathrm{~m}^{2}$ - po czym wykonać stosowne obliczenia: $110 \mathrm{~m}^{2}$ pomnożyć przez 5 i dodać iloczyn $10 \mathrm{~m}^{2}$ razy $20 \mathrm{zł}$. Ostatecznie daje nam to $750 \mathrm{zł}$. Takie ujęcie jest kumulacją wartości liczbowych (parametrów), o których mowa była na początku artykułu. Mamy tutaj bowiem wspomnianą już powierzchnię oraz stawkę, a do tego dochodzi nam także rzeczona kwota 20 zł dla każdego metra powyżej $100 \mathrm{~m}^{2}$ powierzchni. Proste ujęcie normatywne tych trzech wielkości liczbowych (parametrów) daje nam w efekcie dość skomplikowana dla laika formułę obliczania kwoty podatku od nieruchomości.

Możliwa jest też druga ewentualność, o której wspomniano na początku. $\mathrm{W}$ prawie podatkowym obowiąują bowiem normy, które wiążą pewne obowiązki w zależności od wartości wielkości liczbowych (parametrów) z lat poprzednich. Istnieje bowiem norma wyrażona w art. 24a ust. 4 ustawy z 26 lipca o podatku dochodowym od osób fizycznych ${ }^{29}$, która wespół z art. 2 ust. 1 pkt 2 ustawy z 29 września 1994 r. o rachunkowości ${ }^{30}$ nakazuje, aby podatnik będący np. osobą fizyczna, która z tytułu prowadzonej działalności gospodarczej uzyskała przychód w poprzednim roku podatkowym wynoszący równowartość $\mathrm{w}$ walucie polskiej co najmniej $2 \mathrm{mln}$ euro, rozpoczęła, począwszy od 1 stycznia roku następnego, prowadzenie ksiąg rachunkowych.

W przytoczonym powyżej fragmencie normy prawnej możemy odszukać następujące wielkości liczbowe (parametry). Pierwszą z nich jest to, ile będzie wynosić równowartość 2 mln euro po kursie średnim ogłaszanym przez NBP z pierwszego dnia roboczego października poprzedzającego dany rok obrotowy. Mając pierwszą z danych wielkości liczbowych (parametrów), możemy zatem ustalić, na podstawie prawidłowo prowadzonej dokumentacji, czy przychód u podatnika za rok poprzedni osiagnął albo przekroczył wyżej wspomniana równowartość. A zatem czy zachodzi nierówność następująca: $P$ (przychód) jest >= (większy lub równy) $R$ (równowartości 2 mln euro po wspominanym wyżej kursie).

Na początku artykułu wspomniano o normach mających postać: „Ilekroć zaistnieje taki stan rzeczy, że dana wielkość liczbowa wyniesie $Z$ " - to właśnie owym stanem rzeczy jest zachodzenie wspomnianej powyżej nierówności (na którą składają się wartości parametrów). Ilekroć bowiem przychód osoby fizycznej z tytułu prowadzonej działalności gospodarczej wyniesie w poprzednim roku co najmniej równowartość 1 mln 200 tys. euro po wspominanym wyżej kursie, tylekroć winna jest ona od kolejnego roku prowadzić księgi rachunkowe.

${ }^{29}$ Zob. ustawa z 26 lipca 1991 r. o podatku dochodowym od osób fizycznych, Dz. U. 2016, poz. 1860.

${ }^{30}$ Zob. ustawa z 29 września 1994 r. o rachunkowości, Dz. U. 2016, poz. 615. 


\section{WPEYW NORM PARAMETRYCZNYCH NA ELASTYCZNOŚĆ PRAWA}

Akty normatywne zawierajace wiele klauzul generalnych, odsyłających nas do innych systemów norm, potrafia przetrwać nieuchylane przez bardzo długi. Przykładem niech będzie niemiecki kodeks cywilny (BGB) który uchwalony jeszcze za czasów II Rzeszy Niemieckiej, przetrwał I wojnę światowa, Republikę Weimarska, III Rzeszę, II wojnę światowa, a następnie obowiązywał na terenie RFN (od początku XX w. po dziśs dzień) oraz NRD (do 1976 r.). Podobna rolę pełnia normy parametryczne. Przedmiotem ich normowania sa np. wspomniane wyżej tzw. normy techniczne. Te normy zmieniają swoją treść wraz z upływem czasu i postępem technicznym - odesłanie do norm prawa organizacji fachowych dotyczących m.in. głębokości, na jakiej powinny być położone przewody elektryczne, jest zmienne względem kolejnych ustaleń nauki i zastosowania nowych materiałów do produkcji owych osłon. Jednakże istnieja przypadki, kiedy ustawodawca się tym zabiegiem nie posługuje - przykładem jest wspomniane już rozporządzenie Ministra Infrastruktury z 12 kwietnia 2002 r. w sprawie warunków technicznych, jakim powinny odpowiadać budynki i ich usytuowanie i w całości wysławia w przepisach prawa normy parametryczne.

Jest to jednak rozwiązanie o wiele mniej korzystne niż stosowanie odesłań do zbiorów norm parametrycznych stanowionych przez organizacje branżowe. Prawodawca nie jest bowiem w stanie nadążyć za rozwojem technicznym i tylko organizacje fachowe zajmujące się wąskim wycinkiem specjalistycznej wiedzy w danej dziedzinie są w stanie na bieżąco analizować postępy w nauce i dostosowywać normy techniczne do aktualnej wiedzy. Przykładem niech będą obecnie wprowadzane tzw. pojazdy autonomiczne, w których rolę kierowcy przejmują komputery ${ }^{31}$. Ustawodawca reguluje definicję kierowcy w Prawie o ruchu drogowym, przez co nie obejmuje ona klasy sytuacji, kiedy kierowca jest maszyna ${ }^{32}$.

Nowelizacja ustawy to proces rozciagnięty w czasie, nadto wraz z nia należy zmienić szereg przepisów w zakresie obowiązkowej odpowiedzialności cywilnej. W przypadku kiedy to ustawodawca posłużyłby się odesłaniem do zbioru norm branżowych, np.: Polskiego Związku Motorowego jako organizacji fachowej, to wystarczyłoby, aby ta organizacja dokonała nowelizacji swojej normy w zakresie tego, kim jest kierowca i jak kształtuje się jego odpowiedzialnośćc ${ }^{33}$.

Na płaszczyźnie międzynarodowej podobną rolę odegrała Unia Europejska w zakresie rachunkowości. Początkowo powstała w 1973 r. międzynarodowa organizacja w zakresie ujednolicenia standardów rachunkowości finansowej - Komitet Międzynarodowych Standardów Rachunkowości Finansowej. Na-

${ }^{31}$ Pojazdy wprowadzone do użytku po raz pierwszy przez Tesla Motors.

${ }^{32}$ Ustawa z 20 czerwca 1997 r. - Prawo o ruchu drogowym, Dz. U. 2017, poz. 128.

${ }^{33}$ Ustawa z 22 maja 2003 r. - o ubezpieczeniach obowiązkowych, Ubezpieczeniowym Funduszu Gwarancyjnym i Polskim Biurze Ubezpieczycieli Komunikacyjnych, Dz. U. 2016, poz. 2060. 
stępnie został on przekształcony w 2001 r. w Radę Międzynarodowych Standardów Rachunkowości. Następnie w rozporządzeniu Parlamentu i Rady nr 1606/2002 w sprawie stosowania międzynarodowych standardów rachunkowości zawarto podstawę prawną (oraz opis procedury) włączania do systemu prawa UE poszczególnych standardów rachunkowości.

Od 1 stycznia 2005 r. wszystkie spółki giełdowe w UE muszą stosować międzynarodowe standardy sprawozdawczości finansowej. Polska ustawa o rachunkowości nałożyła nadto wymóg stosowania owych standardów także na banki działające na terenie Rzeczypospolitej. W ten sposób cały zespół norm parametrycznych utworzonych przez ciało międzynarodowe został włączony do systemu prawnego krajów członkowskich UE.

mgr Michat Bonczkowski

Instytut Nauk Prawnych Polskiej Akademii Nauk

Warszawa

michalbonczkowski@wp.pl

\section{PARAMETRICAL NORMS}

\section{Sum mary}

The article deals with parametric norms, as a certain type of norm, so far not in the interest of the theory of law. The current achievements of Polish law theories and individual branches of Polish dogmatics are presented and possible areas where these norms can be found have been identified. They include normalisation standards, environmental law standards and financial law standards, all of them referred to as norms. Further, a division into legal parametric norms and non-normative parametric norms is made and the relation of a set of norms to a set of parametric norms as well as the possible impact of parametric norms on the flexibility of law are analysed. 